\title{
The Practice of Political Entrepreneurship in a Rural Javanese Village
}

\author{
Wawan Sobari \\ Master Program of Social Science, Universitas Brawijaya \\ (email: wawansobari@ub.ac.id)
}

\begin{abstract}
This qualitative case study aims to explore the practice of political entrepreneurship in a rural Javanese village. Political entrepreneurship is dictated by the special interest of political entrepreneurs, incentives gained from the political system, and awareness about targeting the change of political institution, an explanation theorized by McCaffrey and Salerno (2011). Unlike the theory, this study assesses the importance of cultural explanation of political entrepreneurship which provides room in an academic discussion. The study reveals the role of Javanese (and Islam) values in encouraging the political entrepreneurship of a village head. Philosophical values of Javanese leadership promoting an exemplary leader (ing ngarso sung tulodo) and leadership behavior that is andap asor (humble) have favored public acceptance of the practice of political entrepreneurship. Furthermore, the doctrine (akhlak) and practices of Islamic rituals by the village head explain the direction of political entrepreneurship. This study discovers also the concept of 'sungkan' demonstrated in respect for the performance of the village head. Moreover, the ability to provide solutions to villagers' problems practiced through suwuk and petungan add gratitude for the village head. Leadership behavior adhering to these cultural and religious values directly or indirectly induced a 'sungkan' effect in a reelection bid (the 2013 Village Election). 'Sungkan', which is equal to electoral accountability, explicates the outcome of political entrepreneurship for the electoral process in the village that were relatively clean from vote-buying. Lastly, the casework expands political entrepreneurship theory, indeed, cultural and religious values can also drive the practice of political entrepreneurship.
\end{abstract}

\section{Keywords:}

electoral accountability; java; village leadership

\section{Introduction}

Decentralization (and village autonomy) and democracy are two important institutional tools driving changes at the regional/village level. Decentralization is assumed to give opportunities to regional and village elites to exercise authority in accordance with the needs and demands of people. Meanwhile, democracy in the election for regional or village leaders provides competitive room to select the best candidates. Thus, decentralization and democracy are theoretically corresponding factors.
Political leadership which is able to deliver public benefits for people in the region/ village explains these corresponding elements. An elected leader can take advantage of decentralization by endorsing innovative and/ or beneficial policies and programs to meet local people or villagers' needs and demands. The leader may allocate better resources, initiate a good policy process, and provide good services during their term in office. This leadership behavior is one of the examples of political entrepreneurship. 
This study takes advantage of McCaffrey and Salerno's (2011) theory of political entrepreneurship classifying three major branches of thought. First is public choice literature most discussing the rent-seeking aspect of political activity. The study explores literature recovered in this first branch which are self-serving politicians (Dilorenzo, 1988), predatory political profit opportunity-seekers (Holcombe, 2002), the improvement of political resources in the short term (Christopoulos \& Ingold, 2011), and the practice of political patronage (Pappas \& Assimakopoulou, 2012).

Second is the entrepreneurial element (alertness and discovery) of political entrepreneurs to gain profit from the political system. It may include ability to provide collective goods (Richelson, 1973), the productive political profit opportunity-seekers (Holcombe, 2002), potential profit opportunities (Shockley, Frank, \& Stough, 2002), a mixture of policy strategies (Gordon \& Stenvoll, 2007), and non-money-making culture (Bitetto, Gilardoni, \& D'Anselmi, 2013).

The last is the new institutionalism focusing on the role of the political entrepreneur to alter (shaping, changing, and consolidating) political institutions. Two identified works from this branch are political entrepreneurial practices of agents of policy change (Hogan, 2006) and securing favored policies (Martin \& Thomas, 2013).

McCaffrey and Salerno (2011), then, define political entrepreneurship as "the direction of coercively obtained resources by the state toward processes of production which would not otherwise have taken place" (that is, would not have taken place in an unrestricted market) (p. 556). This definition further develops the logic of political entrepreneurship to identify who are included as political entrepreneurs. They are anyone who can exercise control over decision-making of public resources allocation. Political entrepreneurs are mainly those who occupy public office as a result of the electoral process as remarked by Roberts and King (1991).

This study, then, interprets that McCaffrey and Salerno's (2011) theory implicitly explains about motives or incentives or driving factors making political entrepreneurship work. The first perspective suggests that political entrepreneurship practices are dictated by special interests of political entrepreneurs, such as predatory political profit opportunities, maintaining patronage links, and political resources. The next branch views incentives gained by political entrepreneurs that may drive their actions. However, McCaffrey and Salerno (2011) theorize that political entrepreneurship does not merely imply economic values. It particularly includes nonmoney-making incentives and collective goods.

The third approach follows the logic that political entrepreneurs are able to target the change of political institutions. It mainly focuses on institutional change that benefits them, such as shaping favored policies and targeting certain policy change.

These three approaches are relevant to McCaffrey and Salerno's (2011) concern in the theory. They largely explain about the logical implication of certain types of political behavior.

Moreover, McCaffrey and Salerno's (2011) definition requires to consider three important aspects in any study of political entrepreneurship, namely ownership, uncertainty, and production. This study interprets each aspect in the three equivalent terms in order to make these elements workable. They are control over the state's resources allocation (ownership), accountability in decision-making (uncertainty), and government production (both public and private goods) for creating public value (production).

Unlike the theory, this study assesses the importance of cultural explanation of the practice of political entrepreneurship and provides room for academic discussion. It is 
different from McCaffrey and Salerno's (2011) political entrepreneurship theory and other relevant studies which explicate political entrepreneurship in three perspectives. This study seeks to explore a cultural (and religious) explanation along with the practice of political entrepreneurship by focusing on the leadership practice of a village head in a rural Javanese village.

This study explores the leadership of the Argomulyo's (pseudonym) Village Head in Trenggalek Regency, East Java as a political entrepreneur while leading the village since 2007. In addition, it seeks to explain the implications of the practice of political entrepreneurship on villagers. Moreover, it is important to explore village electoral democracy lessons obtained from the political entrepreneurship practices at Argomulyo.

Studies exploring the practice of political entrepreneurship in an Indonesian context remain rare, in particular, political entrepreneurship research taking into account cultural explanation as an analytical frame. Thus, this research is a pioneer in the study of political entrepreneurship in Indonesia, especially, in rural Java.

Responding to the importance of considering Javanese culture in explaining the practice of political entrepreneurship, this research formulates a problem statement about the practice of political entrepreneurship in Argomulyo. It explores the practices of political entrepreneurship of village head, villagers' responses, and their implications for electoral democracy in Argomulyo.

Reflecting on the research findings, this paper, then, initiates a normative interpretation about political entrepreneurship. Political entrepreneurship are any efforts of politically elected officials to create or improve public benefits of the production and distribution of public resources. At least the efforts are carried out in three ways, namely the allocation of resources, policy making, and service provision.
In other words, political entrepreneurship is a perspective on the public benefits of a political leadership. Thus, always striving to create public benefit is an important mindset in political entrepreneurship. This perspective strives to demonstrate a more positive overtone of political entrepreneurship compared to McCaffrey and Salerno's (2011) theory of political entrepreneurship and other similar studies.

This distinctive overtone is also relevant to empirical problems in Indonesian rural villages, especially after the enactment of Law No. 6/2014 concerning the Village. Villages face various challenges due to the law stressing on the village government modernization. On the other hand, the law recognizes the right of village origin and encourages the defense of cultures. This dilemma requires village heads, as political entrepreneurs, to compromise modernization and cultural resilience as well as bring public benefits into their leadership practices, results, and outcomes.

\section{Methods}

This study focuses on the practice of political entrepreneurship of the village head in a rural Javanese village. It was conducted in Argomulyo Village (pseudonym), Karangan Sub-district, Trenggalek Regency, East Java from September to October 2017. A qualitative approach as a way of thinking, investigating and interpreting the practice of political entrepreneurship in Argomulyo was employed because of highly value-related content of the natural setting of the study object and the relationship between researcher and participants (Creswell, 2009).

The case study explores the practice of political entrepreneurship in rural Java along with the cultural and non-cultural explanations by examining entrepreneurial political leadership and achievements, Javanese values and philosophy endorsing village head leadership, and the impact of political 
entrepreneurship on electoral politics or village election (pilkades).

To achieve this goal, in selecting cases and obtaining and analyzing data, this study applied intrinsic casework which is regularly begun with cases already identified (Stake, 1994). Argomulyo was chosen because the village head candidates were prominent not to perform money politics in the pilkades (Mr. Dono, personal communication, August 2, 2017) (pseudonym, a staff of Community and Village Empowerment Agency (PMD) of Trenggalek). This good electoral practice is in contrast to many others pilkades in the regency colored by vote-buying practices. It convinced this study to scrutinize what factors contribute to the ineffectiveness of money politics in Argomulyo's Pilkades through political entrepreneurship theory as an academic lens.

\section{The Village}

Argomulyo is one of the 12 villages in Karangan Sub-district, in Trenggalek whose cultural features are included in Java Mataraman of the East Java Regional Division of Culture (Sutarto \& Sudikan, 2008) and as Mancanagari or 'outer region' according to Koentjaraningrat's classification of the regional diversity of Javanese culture (1990). The characters of the outer region's culture are similar to the central Javanese court culture of Yogyakarta and Surakarta whose culture capitals perform syncretism in religious life, unifying elements of Hinduism, Buddhism and Islam.

Argomulyo itself covers 4 hamlets, namely Gondang (pseudonym), Sapto (pseudonym), Kerto (pseudonym), and Raharjo (pseudonym), 12 community units (RW), and 27 neighborhood units (RT). The population of Argomulyo reached 4,201 people in $2016(2,157$ males and 2,044 females). All inhabitants are Moslem. Elementary school (SD) graduates dominate villagers' education level by $53 \%$.
The majority residents' livelihoods (18-56 years old) are peasants and livestock farmers. Argomulyo has some active community organizations, such as farmer groups, family welfare movement (PKK), and Karang Taruna (youth organization). Argomulyo's village head chairs the government structure with eight working units. There is also the village head's partner, namely the Village Consultative Board (BPD) comprises of nine members.

In Trenggalek, including in Argomulyo, the leadership of a village head cannot be separated from the existing Javanese culture. In particular, a village head receives an honorable appellation as "Mbah Lurah" whom the villagers regard as an elder person due to his leadership maturity and contribution.

\section{Result and Discussion}

Entrepreneurial Political Leadership and Achievements (2007-2017)

A young village head named Atmono (pseudonym) has led Argomulyo since 2007. He was born in Argomulyo and obtained a master degree in education from a local university in Trenggalek. Atmono started his career as the member of BPD of Argomulyo in 2001 when he was appointed, not elected as a BPD member to represent youths. Atmono occupied the BPD office while serving the Ansor Youth Movement (GP Ansor) of Karangan Sub-district. He had served as GP Ansor for two terms (2001-2006). Prior to lead GP Ansor, Atmono had served as a chair of the Student Association of Nahdlatul Ulama (IPNU) of Karangan Sub-district (19992000) (Atmono, personal communication, September 8, 2017).

A consistent career in Moslem-mass based organizations (MBO) has promoted his leadership skills and socio-political networks. The organizations, in which he is involved, are affiliates to Nahdlatul Ulama (NU), the biggest $\mathrm{MBO}$ in Indonesia. His organizational careers made him gain considerable support, especially from the youths in Argomulyo. Also, 
his leadership skills and experiences gave him an important foundation for competing in the village political arena in 2007. Moreover, the humble leadership makes Atmono gain sympathy, trust, and respect (sungkan) from the youths.

His closeness and respect in communicating with anyone allowed Atmono to easily gain villagers' trust when he ran in the reelection bid (2013). He did not need to deploy a vote-buying (exchange money or goods for votes) strategy for every ballot he earned, which the other candidates in many pilkades in Trenggalek commonly did. Atmono remarked, "Alhamdulillah (thanks for god) with that pattern (due to sungkan), I did not give anything to voters (given the material reward for choosing him)" (personal communication, September 8, 2017). He also said:

(My leadership) I started with the language of toto kromo, polite Javanese language. So when (communicating) with anyone, including with younger people, I prefer to use toto kromo, polite Javanese language, as well as when I talked with my fellows. We usually use polite Javanese to people above us, while I don't, to my level and below me, I often use polite language (personal communication, October $21,2017)^{1}$

By applying this communication method, he gained $78 \%$ of the ballots in the 2007 Pilkades. Furthermore, in the 2013 Pilkades, there were only 24 people who did not vote for him. Voter turnout in the election reached $85 \%$ (personal communication, September 8, 2017).

The achievements (outputs and outcomes) during his leadership, including development priorities, demonstrate the practice of political entrepreneurship of Argomulyo's Village

\footnotetext{
1 A female karang taruna administrator as well as one of the committee members of the 2013 Pilkades strentheneed these facts.
}

Head. During his leadership from 2007 to 2017, Atmono had established three main programs. First is the improvement of public service quality such as setting the computerized administrative service at the village office. Besides, infrastructure (roads) has been reported improved, with around $85 \%$ of the village's roads in good condition as of October 2017. The village also succeeded in implementing a national program called PAMSIMAS (Water Supply and Community Sanitation) which is operationally managed by BUMDes (village-owned enterprise) ${ }^{2}$ and added a project of communal wastewater treatment plant (IPAL) in collaboration with District Public Works Agency and Housing (PUPR) (a young hamlet head, personal communication, October 22, 2017).

Moreover, the villagers' ethic and strengthening values and teachings of Islam in Argomulyo have improved. Although the outputs are less tangible, but they can improve villagers' life quality. Previously, one of the bad habits of Argomulyo's youths was to gather aimlessly while drinking alcoholic beverages (mendem). Atmono's approach by using polite Javanese language (kromo) made them feel embarrassed (sungkan in terms of feeling ashamed or isin) when they met him. The youths, then, stopped their mendem habit (personal communication, September 8, 2019).

During his leadership, Atmono was also able to eliminate the habit of charging a heavy fine for cheating couples. Atmono compelled all RT heads not to set the penalty. The village suspended development projects in RT areas that insisted on setting customary fines (personal communication, October 9, 2019).

\footnotetext{
2 Interview conducted on September 8, 2017. Also, Atmono claimed that within his leadership, the village succeeded to builth drainage. Interview with a young hamlet head remarked that all village roads have been covered by asphalt. (personal communication, October 22, 2017).
} 
Atmono's social initiatives and leadership are evidence of the political entrepreneurship practices which shows his ability to restore social life and meet villagers' spiritual needs. Atmono was able to revive some religious activities. One of the Karang Taruna administrators said: "Mbah Lurah tends to concern more in religion, for example weekly yasinan ${ }^{3}$ conducted every Wednesday, that was previously not running, is now running in Argomulyo. The activities (weekly yasinan) regularly move among mosques and prayer rooms (mushola)."

Atmono directly admitted that religious activity is one of the development priorities he undertakes. In addition, religious activities are part of his efforts to approach and interact with the villagers directly. "With the approach of spiritual language through groups of yasin and other groups, people are spiritually and ethically 'kenek' (can be) connected" (personal communication, September 8, 2017).

The sincerity of devotion and willingness to serve the villagers, even outside village head's duties, became an important credit for Atmono's political entrepreneurship practice. Another hamlet chief revealed:

\footnotetext{
3 In Java, yasinan is popular both for Javanese performing Javanism (kejawen) in their lives and traditional Javanese santri. Yasin epistle recitation is part of Muslim funeral rites practiced several days after death and as collective veneration of a teacher or respected person. In East Java, yasinan is an identical religious expression of Nahdlatul Ulama (NU)'s followers. Therefore, yasinan can tell us about the presence of NU tradition in expressing Islam in Argomulyo.

4 A village apparatus called the activity as circular manjelis taklim that was successfully mobilized by the village head (personal communication, October 22, 2017). Atmono conveyed also that the chief of Karang Taruna and him have initiated and led the Wali Songo (nine Islam saints) Pilgrimage for villagers in the last several years (personal communication, October 21, 2017). While a BPD's member said that the village head routinely mobilizes donation for orphans in Argomulyo. Moreover, in the last two years (20162017) the village head initiated the ceremony of village cleaning (personal communication, October 22, 2017).
}

\begin{abstract}
"Mbah Lurah has never been reluctant. He is always available, even when very busy. For example, in the same day and schedule, he is available to participate (deliver speech) in wedding ceremonies (manten or besan). At the same time, he can handle up to three weddings and he can run them. Anyway, all villagers' requests are met (personal communication, October 22, 2017). ${ }^{\prime \prime}$
\end{abstract}

The willingness to spend time on villagers' activities is an additional credit for Atmono's political entrepreneurial profile. For villagers, a village head is not only a government manager, but also performs as a social leader, social servant, and social solution provider to villagers.

In addition, the village head was able to initiate the establishment of an alternative education facility for villagers. Since the beginning of his office, Atmono founded an Islam-based elementary school, namely Madrasah Ibtidaiyah (MI) Darul Ulum. Atmono has served as the board of the foundation and the principal simultaneously.

Villagers recognize the existence of MI and consider it successful in encouraging students to be equal and compete with other schools in Trenggalek. One of the MI's students gained an outstanding achievement at the regency level in 2017.

The success of infrastructure development in Argomulyo required big funds. It was difficult to meet the expenditure by relying only on the village budget (APBDes). Nevertheless, the village head was able to achieve rapid infrastructure development, especially roads. The capability of the village head to establish connections with district and provincial

\footnotetext{
5 A female member of BPD delivered the same testimony that Atmono is a handy person, willing to help any villagers' problems, although outside his main duties as village head. (personal communication, October 22, 2017).
} 
legislators and local government eased him to access the funds, including the success of lobbying in the construction of IPAL (One of the Hamlet heads, personal communication, October 21, 2017).

Through his strong connection, the village head was able to actively access infrastructure development projects. Another head of hamlet called the activity of seeking development funds from policy makers (district, province, national) as nyenggek in Javanese term. He remarked:

"Mbah Lurah's breakthroughs to actively access funds (nyenggeki) are always successful. Prior to the policy of village fund allocation (dana desa), there could be projects (gained from nyenggek) from Jasmas (community aspiration net fund of East Java Legislators), from local legislators, and from Perkim (Local Agency for Housing and Settlement). Previously, there was a budget from PPIP (Rural Infrastructure Development Program)." 6

In Javanese, the term nyenggek means literally picking fruit on a high place using a long piece of bamboo. The term nyenggek is an allegory, which means the activity of mediating discussions between the village and district legislators and/or provinces and/or ministries. Nyenggek has been found in many areas (Sobari, 2017), it is a way to access projects from the central government by bribing national legislators and certain ministry officials.

The village head's political entrepreneurship practices are relevant to McCaffrey and Salerno's (2011) theory. He does not only practice worthy leadership, but also uses his networks with politicians and bureaucrats to get some development projects

\footnotetext{
6 The same and strengthening opinion was also expressed by a female member of BPD (personal communication, October 22, 2017).
}

implemented in Argomulyo. He is also able to build social and religious institutions that are accepted by the villagers.

In other words, leadership practice that always strives to provide public benefits (public value) is a manifestation of political entrepreneurial leadership. However, it is too naive if we neglect the entrepreneur's political calculation. Beyond public value-based outputs and outcomes of leadership performance, the village head may calculate his self-interest motives and target institutional changes that will favor him to gain political credit from villagers, a belief that is confirmed by McCaffrey and Salerno (2011).

\section{Javanese Values and Philosophy in the Village Leadership (2007-2017)}

Javanese culture dominates daily life in Argomulyo. The use of Javanese in daily communication among villagers indicates this existing culture as observed from the use of Javanese Mataraman dialect and its polite language in daily communication and during interviews. During interviews with the village head, elites, and villagers, the researcher often recorded the use of the word ngapunten (apologize) before conveying an opinion or an answer to a given question. Moreover, the participants' intonation sounded low which expresses the habits of the Javanese Mataraman people.

Javanese values and philosophy contribute to the leadership practice and political entrepreneurship of the village head. Atmono used some philosophies of Javanese leadership during his tenure. First, he applied the exemplary principle where a leader should exemplify the goodness that will be judged and copied by his people. Atmono said:

"Ki Hajar Dewantara principle, if we go back to 'ing ngarso sung tulodo', it indeed is relevant to the term by Rasulullah (Muhammad SAW), sir. So if I use "Innama buitstu li utammima ma karimal akhlaq", 
Rasulullah was sent only to fix morality. It shows that religion is ahlak (morality). I combined with Ki Hajar Dewantara's principle."

In simple terms, the principle of ing ngarso sung tulodo is an important reference for the village head. ${ }^{8}$

Atmono also performed leadership behavior of andap asor (humble) by constantly using polite language during his leadership. In Javanese leadership, andap asor represents the personality of a leader who is not arrogant about his power and always modest (Yana MH, 2012). For the village head, the use of kromo language is able to eliminate distance between the leader and the people and give appreciation to the interlocutors, especially village elites (Atmono, personal communication, September 8 , 2017). Using polite Javanese language to anybody raises a sense of sungkan which in this context means respect to the village head (personal communication, September 8, 2017). Sungkan from villagers led to the absolute win in the reelection bid in 2013. A hamlet head who lives near the village office explained his observations:

"At that time (pilkades 2013) there was, indeed, no rival. I judged it was due to sungkan. This means that if my house is far away and I didn't come (to TPS), I thought that he would probably (Atmono) win. Nevertheless, I still attended

\footnotetext{
Ki Hajar Dewantara is one of Indonesia's educational figures and was designated a national hero by the government of Republic of Indonesia on 28 November 1959 (personal communication, September 8, 2017).

8 Three principles of leadership according to $\mathrm{Ki}$ Hajar Dewantara, firstly, ing ngarsa sung tulada, that is, led by example. The leader must be an example for his subordinates. Secondly, ing madya mangun karsa, that is, in the middle develop the will or intention. Leaders must struggle with their subordinates. Thirdly, tut wuri handayani, that is, from behind gives encouragement. In some moments, the leader lets the subordinates do themselves.
}

(to TPS), because I (felt) sungkan" (personal communication, October 22, 2017).

A female Karang Taruna remarked that villagers were more sungkan not to come to the pilkades polling station (TPS) than not to come to the 2015 Pilkada (election for regional head)

TPS. She said straightforwardly:

"Compared to the regent coblosan (pilkada), villagers were eager (attended) to pilkades. To the pilkada, the villagers considered that they have to exchange a working benefit (income) for one-day election, because there is no change (as the impact of the election) and lack of awareness of villagers (many villagers were absent). It was different with pilkades; they were sungkan to the village head (if not attending at TPS)" (personal communication, October 22, 2017).

Furthermore, villagers believe that the village head has a special spiritual capability. Atmono has provided consultations with villagers who have personal or family problems. Atmono also can help them to find the right day (good) to hold certain celebrations, such as the day of marriage, circumcision, moving to a new house, travelling far away from home, and other purposes (hajat). In the interview, Atmono also explained:

"Every day, there are dozens of people who consult and so forth. I, if requested for a prayer, see the context. There are villagers (who consult) because their children are naughty, who have no children, some children do not want to school, some villagers request for their children' prayer since they do not have school fees" (personal communication, September 8, 2017).

While waiting for interviews with Atmono, the researcher met with villagers 
and non-Argomulyo residents who would to consult with him.

Atmono mentions two special terms, namely dongke and betaljemur that are important in his consultation practice (personal communication, September 8,2017). Betaljemur is a set of the priests' books containing predictions (calculation of good days, bad days, and others). Betaljemur contains various Javanese rituals (Sudardi, 2015), the determination of good days (petungan) (Kutanegara, 2002), and the determination of the types of diseases based on the day of commencement of illness (Sudardi, 2002). The majority of Betaljemur books contain petungan (calculations), especially the Betaljemur Adammakna authored by Prince Tjakraningrat or Patih Danuredjo VI. Of the 337 articles in the book, the author wrote the theme of petungan 212 times (Kalimullah, 2016). Atmono clearly mentioned that he referred more to Betaljemur Adammakna (personal communication, September 8, 2017).

Javanese tradition recognizes petungan as the Javanese numerological system. The Javanese believe in the almighty will (sing kuoso) over human's life. Hence, to achieve salvation or avoid peril, Javanese must follow the order or a fundamental metaphysical concept of Javanese tjotjog or cocog (fit). In the broadest and abstract sense, $\operatorname{cocog}$ is a harmonious relationship between two separate elements. According to Geertz (1960), cocog:

"...implies a contrapuntal view of the universe in which what is important is what natural relationship the separate elements-space, time, and human motivation - have to one another, how they must be arranged in order to strike a chord and avoid a dissonance."

Based on this belief, the petungan system provides a way to harmonize the natural relationship of the elements of human life, then adjust the activities or actions to avoid disharmony with the natural order of nature that can bring disaster or misfortune if not obeyed (Geertz, 1960). Atmono is able to perform petungan for villagers intention of doing certain activities (hajat) in order to find an appropriate day for the implementation. A number of participants recognized the ability and practice of spiritual consultation of the village head. A female Karang Taruna administrator used the term karomah to describe Atmono's ability to provide consultation with villagers.

"Hehas the basics of religious science because he was mondok (graduated from Islamic boarding school). I saw many people requested for treatment. He has the (spiritual) ability; my father said that Mbah Lurah has karomah, so his prayer is granted" (personal communication, October 22, 2017).

A hamlet head affirmed the explanation that Atmono has the spiritual ability to perform a non-medical "treatment" to find solutions to individual or family problems, including residents outside Argomulyo (personal communication, October 21, 2017).

As a result, Atmono's leadership incorporating the Javanese and Islamic leadership philosophy created sungkan among villagers. The feeling of sungkan has many meanings. Firstly, sungkan means a gratitude for the village head for coming to every villager's invitation and undertaking celebrations (hajatan) such as marriage, circumcision, and death. Secondly, sungkan arises because Atmono's strong leadership generated changes or improvements in Argomulyo's infrastructures and other development projects. Villagers praised his leadership initiatives to complete the development of roads, bridges, drainage systems and irrigation. Moreover, Atmono is able to serve citizens' spiritual and mental needs and the harmonization of natural elements and sing kuoso through petungan.

The concept of sungkan as the appreciation of electoral accountability performance of the 
village head is relevant to the sungkan concept in the context of communal relations of the Javanese. Sungkan is showing respect and courtesy to an older or elderly person (Geertz, 1961).

In explaining villagers' electoral behavior, the meaning of sungkan is relatively close to the concept of ewuh pakewuh. According to Tobing (2010), ewuh pakewuh emerges from feeling uncomfortable because individuals feel they have received kindness (help) from others. The Javanese will feel ewuh pakewuh to refuse the request or debate the opinion of others who are disungkani (respected) for the good of the person (as cited in Frinaldi \& Embi, 2014).

The sungkan effects remarked by Argomulyo's elites are confirmed by villagers. The next discussion presents information about villagers' voices regarding Atmono's performances in chairing Argomulyo. These voices can indicate the impact of political entrepreneurial leadership of the village head on villagers' rationales to vote for Atmono in the 2013 Pilkades.

\section{Impact on Village Electoral Politics}

This study investigates villagers' opinions about their response to the political entrepreneurship practice performed by the village head during his first term in office (2007-2013). The responses are important to discover the electoral impact of political entrepreneurship on villagers.

The first question addressed to villagers and voters was about their enthusiasm to participate in the 2013 Pilkades, in which Atmono as an incumbent ran in the reelection bid. A female grocery shop owner, elementary education graduate remarked:

"Attended (to TPS in the 2013

Pilkades at the village hall). (We) both like (with husband) Mbah Lurah. He is very close with my husband. They run Ngaji Reboan (Islamic weekly study every Wednesday). Hence, he seems to be a dhulur lanang (elder brother)" (personal communication, October 22, 2017).

About the results of development in Argomulyo during Atmono's first office (20072013), she added:

"Many infrastructures are good. There is much advancement. (Relationship) to the community is very good. When a villager dead, Mbah Lurah wanted to come. He also came to the commemoration, even led the ceremony" (personal communication, October 22, 2017).

A female farmer, elementary school and boarding school graduate, born in Argomulyo strengthened the statement. She came to TPS and voted for Atmono in the 2013 Pilkades.

"The candidate (Atmono) has the same passion (with me), so I supported him one hundred percent, (he) graduated from Islamic boarding school (mondok). The reason is that he is friendly, kind, religious; to the villagers is 'srawung' (want to interact). His leadership was very good. If there is a problem, it is enough to solve in the village only. His personality is modest. In addition, the village hall is repaired; the village areas (roads) are good. What stands out is about his religion. He regularly attends Islamic studies every Tuesday night" (personal communication, October 22, 2017).

Meanwhile, a male peasant (62 years old), elementary school graduate, who has lived in Argomulyo since 1981 voted for Atmono because he is better than the predecessor. He remarked:

"Alhamdulillah (praise to the God), sir, compared to the previous village head (he is) much better. Now the village's roads are good; he is 'srawung' to villagers. The village head is close with villagers" (personal communication, October 22, 2017). 
A male participant (56 years old), an elementary school graduate, a vice-chairman of a farmer's group, and living in Argomulyo since 1971 saw Atmono as the best leader in Argomulyo.

"I joined the election committee in the pilkades. Argomulyo's village head was no rival. For a simple matter, he wanted to usher the corpse. Everyone said he would be voted until out of perform (sak'eleke). Very good, there are no problems. In Argomulyo, I think he is the best village head. The roads in other villages are not as good as (in Argomulyo); the asphalt is good" (personal communication, October $22,2017)$

In addition, the participant added that the village head deployed the yasinan media to meet with the community. He attended ceremonies at mosques and mushola (praying rooms) to explain a lot of information, including village programs.

A female high school graduate who has lived in Argomulyo since 2009 expressed the same opinion. She came to TPS during the 2013 Pilkades and voted for the incumbent because he would be close to villagers. She viewed the village head is 'cancut' (want to take part in villagers' activities). She added that the village's hall is now good. The appointed village apparatuses are qualified (personal communication, October 22, 2017).

Results from the interview conducted in another location (RT 26 RW 12) strengthen the finding. The change of interviews location is part of the effort to deepen and look for variations of other responses related to the villager's opinion on Atmono's performance and their electoral behavior during the 2013 Pilkades. In fact, there are no different answers from their electoral responses to the leadership and political entrepreneurship of the village head.
A homemaker (42 years old), vocational high school graduate who has lived in Argomulyo since 2001 declared voting for Atmono in the 2013 Pilkades due to the reason as mentioned:

"The person is nice, friendly, populist (want to interact with commoners). Argomulyo has a lot of progress led by Mr. Atmono. Many roads have been covered by asphalt and (he is) active to chair Islamic activities (majelis taklim)" (personal communication, October 22, 2017).

Atmono's two successful achievements that obtained positive responses from villagers are the provision of social services and the benefits of infrastructure developments. The village head is willing to connect with villagers and to engage in religious activities. Moreover, villagers credit his leadership for the progress of infrastructure development in Argomulyo.

Meanwhile, a male participant (36 years old), vocational graduate and furniture artisan, born in Argomulyo, stated Atmono's extraordinary capability as a leader who could also help people with certain problems, including medical problems, through prayers (suwuk) for villagers and non-villagers. He remarked:

"I am worried what would happen if the elected village head was not Mr. Atmono, I cannot imagine. I see that he is capable, even doing 'suwuk'. The most important, he doesn't want to accept money (from suwuk), his service is selfless)" (personal communication, October 22, 2017).

A female tailor (27 years old), junior high school graduate, and has lived in Argomulyo since 2001 declared Atmono as the best candidate) (personal communication, October $22,2017)$. Then, she added the reason for Atmono's success was to provide social services for villagers. 
"Good sir, he always attends Islamic Study held by villagers. He also attended wedding ceremony. To bereaved families, he visits for takziyah (deliver condolence). Village's roads are very good, as you have seen)" (personal communication, October 22, 2017).

She acknowledged also that Atmono was transparent during his leadership. He opened access for villagers to know Argomulyo's development programs and funding.

"In terms of infrastructure, developments are good; the government (management) is good. Whatever (public affairs) in the village is not hidden. The village meetings (policies) were conveyed to villagers. Whether it is (about) development or funding, all are communicated to villagers" (personal communication, October 22, 2017).

A local university student (22 years old), who was born in Argomulyo conveyed the reason for voting Atmono in the 2013 Pilkades. She rationally explained:

"Very good, during these two periods, Argomulyo has been continuously better. The village head is good; his behavior is good. Attendance to TPS is obligation. Whom I vote for (Atmono) is good. Many (villagers) say his religion is good, roads, drainage are better. The social aspect is a lot of aid for the poor. The old widows are also aided" (personal communication, October 22, 2017).

In addition, a senior male participant (70 years old), elementary school graduate, farmer, born in Argomulyo expressed his opinion about Atmono's leadership behavior that is analogically corresponding to the song of LirIlir belonging to Sunan Kalijaga. He answered shortly in Javanese, "Sae ningali perbuatane. Piyambake 'lare angon' (his behavior is good. He is a shepherd boy)". Then, he explained the analogy of 'lare angon' in polite Javanese, "Kemajuane katah, jalan-jalan niku (bagus), Srawungane niku sae, termasuk ngobati tiang sakit. Saniki enten kematian niku dugi" (There are many progresses, village roads are good; his interaction is good, including curing sick villagers. He will visit the bereaved families soon after acknowledging it)) (personal communication, October 22, 2017).

The term lare angon or bocah angon (shepherd boy) has a deep parable meaning over the leadership of a village head. In the Lir-Ilir, the term angon means the capacity and leadership behavior of a leader. Cah angon reflects a leadership philosophy that provides real examples to guide people (Rosmiati, 2014).

Then, a male participant and village member who was born and lived in RT 26 RW 12 explained villagers' electoral political behavior in the 2013 Pilkades. He explained some examples of Atmono's electoral accountability during his leadership (2007-2017).

"Maybe (villagers) wanted to vote for Pak Atmono. In the community (before occupying village office), he previously had often appeared (performed). He is easy to help others, whoever is difficult to refuse (him). Villagers feel, directly or indirectly, want to vote for him" (personal communication, October 22, 2017).

Therefore, it was difficult for villagers (sungkan) not to reelect Atmono in the 2013 Pilkades.

The elucidation of voters in the 2013 Pilkades demonstrates two important findings. Firstly, the practice of Atmono's leadership as a political entrepreneur is able to provide the outputs and outcomes of infrastructure and social development equally. Villagers mainly credit him for infrastructure development achievements, especially roads. 
Secondly, villagers consider Atmono close to them because he wants to srawung. In Javanese terms, srawung means gathering or meeting held by more than one person or group. In the tradition of rural Javanese people, this term includes chatting, or media to tell each other about the reality of life (Gunawan, 2016). Villagers regard the village head as their mate to tell about their lives. Villagers feel their leader pays special attention by srawung.

Atmono also deploys srawung in religious activities. Therefore, villagers consider Atmono as a populist (person who is close to them) and a religious person. He often exhibits his srawung in several religious moments, such as takziyah (deliver condolence), mass prayer (istigoshah), yasinan, and villagers' hajatan, and encourages social aid movements for the weak and vulnerable.

\section{Conclusion}

This study expands the theory of political entrepreneurship on three theoretical perspectives of political entrepreneurship. It considers that the theory not only discusses what drives the behavior of political entrepreneurs, but what makes the practice of political entrepreneurship work and have an impact. This study explains that leadership and interaction models between leader and people (humble and populist) make political entrepreneurship practices acceptable and creditable (gain positive responses) by citizens.

Moreover, political motives (rentseeking), incentives (profit gained from political system), and the desire to influence institutional change are not the only driving factors. Javanese culture can also expand the explanation of how political entrepreneurship works. Philosophical values of Javanese leadership promoting an exemplary leader (ing ngarso sung tulodo) and leadership behavior that is andap asor (humble) have favored public acceptance of the practice of political entrepreneurship of the village head. Furthermore, the doctrine (ahlak) and practices of Islamic rituals by the village head and villagers explain the direction of political entrepreneurship.

The ability to provide solutions to villagers' individual or family problems practiced through suwuk and petungan add gratitude for the village head. Leadership behavior adhering to these cultural and religious values directly or indirectly induced a 'sungkan effect' in the 2013 Pilkades. Firstly, villagers felt sungkan not to attend TPS. Secondly, they also felt sungkan for not voting for the incumbent. This study then interprets sungkan as respect and gratitude.

Villagers' voices clarify the electoral effects of political entrepreneurship. Advancement in the village's infrastructure and social conditions are perceived as the village head's electoral accountability to villagers. It provided sufficient electoral effects to encourage the absolute victory of the incumbent village head in the 2013 Pilkades. In other words, electoral accountability is an outcome of political entrepreneurship.

Apart from the progress of development, the Javanese terms of srawung (gathering and chatting), cancut (not only giving orders, but also engaging directly with villagers), and the cah angon leadership explain the sungkan effect in the 2013 Pilkades. Accordingly, 'sungkan' is a genuine concept of appreciation of electoral accountability among Javanese villagers, especially in Argomulyo.

\section{References}

Bitetto, D. M., Gilardoni, G., \& D'Anselmi, P. (2013). Separating the Useful from the Beautiful. In M. Bitetto, G. Gilardoni, \& D. Paolo (Eds.), SMEs as the Unknown Stakeholder (pp. 153-176). London: Palgrave Macmillan.

Christopoulos, D., \& Ingold, K. (2011). Distinguishing between political brokerage \& political entrepreneurship. Procedia-Social and Behavioral Sciences, 
10(2011), 36-42. doi: 10.1016/j. sbspro.2011.01.006

Creswell, J. W. (2009) Research design: Qualitative, quantitative, and mixed methods approaches. Thousand Oaks, California: Sage Publications.

DiLorenzo, T. J. (1988). Competition and political entrepreneurship: Austrian insights into public-choice theory. The Review of Austrian Economics, 2(1), 59-71. doi: 10.1007/BF01539298

Frinaldi, A., \& Embi, M. A. (2014). Budaya kerja ewuh pakewuh di kalangan Pegawai Negeri Sipil Etnik Jawa (Studi pada Kabupaten Pasaman Barat, Provinsi Sumatera Barat). Humanus, 13(1), 68-75. doi: 10.24036/jh.v13i1.4099

Geertz, C. (1960). The Religion of Java. Chicago and London: The University of Chicago Press.

Geertz, H. (1961). The Javanese Family. USA: Free Press of Glencoe.

Gordon, R., \& Stenvoll, T. (2007). Statoil: A study in political entrepreneurship. Paper presented at The Changing Role of National Oil Companies in International Energy Markets, Japan.

Gunawan, Y. (2016, November 7). Melestarikan budaya srawung. Unika. Retrieved from http://news.unika.ac.id/2016/11/ melestarikan-budaya-srawung/

Hogan, J. (2006). The contribution of political entrepreneurs to policy change at times of crisis. Financial Times, 15.

Holcombe, R. G. (2002). Political entrepreneurship and the democratic allocation of economic resources. The Review of Austrian Economics, 15(2-3), 143159. doi: 10.1023/A:1015758419984

Kalimullah, M. (2016). Primbon dalam budaya Jawa: Studi tekstual-komprehensif kitab Betaljemur Adammakna dan aplikasinya dalam masyarakat (Doctoral dissertation, UIN Surabaya, 2016). Surabaya. Indonesia: UIN Surabaya.
Koentjaraningrat. (1990). Javanese culture. Singapore: Oxford University Press.

Kutanegara, P. M. (2002). Peran dan makna sumbangan dalam masyarakat pedesaan Jawa. Populasi, 13(2). 41-59. doi: 10.22146/ jp.11827

Martin, A., \& Thomas, D. (2013). Two-tiered political entrepreneurship and the congressional committee system. Public Choice, 154(1-2), 21-37. doi: 10.1007/ s11127-011-9805-z

McCaffrey, M., \& Salerno, J. T. (2011). A theory of political entrepreneurship. Modern Economy, 2(4), 552-560. doi:10.4236/ me.2011.24061

Pappas, T. S., \& Assimakopoulou, Z. (2012). Party patronage in Greece: Political entrepreneurship in a party patronage democracy. In P. Kopecky, P. Mair, M. Spirova (Eds.). Party patronage and party governments in European democracies (pp. 144-162). Oxford: Scholarship Online.

Richelson, J. (1973). A note on collective goods and the theory of political entrepreneurship. Public Choice, 16(1), 73-75. doi: 10.1007/BF01718808

Roberts, N. C., \& King, P. J. (1991). Policy entrepreneurs: Their activity structure and function in the policy process. Journal of Public Administration Research and Theory, 1(2), 147-175. doi: 10.1093/ oxfordjournals.jpart.a037081

Rosmiati, A. (2014). Teknik stimulasi dalam pendidikan karakter anak usia dini melalui lirik lagu dolanan. Resital: Jurnal Seni Pertunjukan, 15(1), 71-82. doi: 10.24821/resital.v15i1.801

Shockley, G., Frank, P., \& Stough, R. (2002, March). Toward a theory of public sector entrepreneurship. Paper presented at The NCIIA 7th Annual Meeting: Big Ideas of The Small World, Boston.

Sobari, W. (2017). Patronage driven democracy: Emerging local politics in the Post-Soeharto 
Indonesia. Surabaya: Airlangga University Press.

Stake, R. E. (1994). Qualitative case studies. In N. Denzin \& Y.S. Lincoln (Eds.). Handbook of Qualitative Research (pp. 134-164). California: Sage publications, Inc.

Sudardi, B. (2002). Konsep pengobatan tradisional menurut primbon Jawa. Humaniora, 14(1), 12-19. doi: 10.22146/jh.v14i1.740
Sudardi, B. (2015). Ritual dan nilai islami dalam folklor Jawa. $I b d a^{\prime}, 13(2), 112-122$. doi: 10.24090/IBDA.V1312.665

Sutarto, A., \& Sudikan, S. Y. (2008). Pemetaan kebudayaan Propinsi Jawa Timur: Sebuah upaya pencarian nilai-nilai positif. Jember: Biro Mental Propinsi dan Kompawisda Jatim.

Yana, M. H. (2012). Falsafah dan pandangan hidup orang Jawa. Yogyakarta: Bintang Cemerlang. 